\title{
Porites ulcerative white spot disease: description, prevalence, and host range of a new coral disease affecting Indo-Pacific reefs
}

\author{
Laurie J. H. Raymundo ${ }^{1, *}$, C. Drew Harvell ${ }^{2}$, Taylor L. Reynolds ${ }^{3}$ \\ ${ }^{1}$ Silliman University Marine Laboratory, Dumaguete City 6200, Philippines \\ ${ }^{2}$ Section of Ecology and Evolutionary Biology, Cornell University, Ithaca, New York 14853, USA \\ ${ }^{3}$ Department of Microbiology, Pathology and Parasitology, North Carolina State University, College of Veterinary Medicine, \\ Raleigh, North Carolina 27606, USA
}

\begin{abstract}
The results of an investigation of a new coral disease affecting Indo-Pacific reefs are presented. Porites ulcerative white spot disease (PUWS) is characterized by discrete, bleached, round foci, 3 to $5 \mathrm{~mm}$ in diameter, that may either regress or progress to full tissue-thickness ulcerations that coalesce, occasionally resulting in colony mortality. Monitoring of 25 diseased and 5 healthy reference colonies for 17 mo revealed that advanced stages of the disease were characterized by lesion coalescence, partial colony death (i.e. portions of the colony still alive; $\mathrm{n}=17$ ) and total colony death $(n=2)$. Field transmission experiments revealed that $95 \%$ of healthy colonies developed lesions within 5 wk after continual exposure to diseased branches, while $60 \%$ of the reference colonies remained healthy. The host range of PUWS includes branching and massive Porites spp., and prevalence per species was positively correlated with species density. On 10 reefs surveyed in the Central Philippines, $22 \pm 7 \%$ (mean $\pm \mathrm{SE}$ ) of poritid colonies were infected, and the disease was present on $80 \%$ of the surveyed reefs. Poritids are dominant Indo-Pacific reef builders; a disease targeting this genus could cause major shifts in community structure over time. This report contributes to the limited knowledge of PUWS impacts in this region.
\end{abstract}

KEY WORDS: Coral disease $\cdot$ Ulcerative lesion $\cdot$ Porites $\cdot$ Indo-Pacific $\cdot$ Host range $\cdot$ Disease prevalence

Resale or republication not permitted without written consent of the publisher

\section{INTRODUCTION}

Pathogens are one of several structuring forces in marine communities, especially when they negatively affect a dominant species or major interactor (Peters 1989, Aronson \& Precht 1997, Kim et al. in press). Acute epizootics that cause rapid mass mortality of a species playing a significant role in community structure may cause a phase shift such as that from a coraldominated to a macroalgae-dominated community. Such a transition occurred as a result of the Diadema antillarum epizootic on Jamaican reefs (Liddell \& Ohlhorst 1986, Carpenter 1990, Hughes 1994), and recent evidence suggests little subsequent recovery of the urchin populations in communities that continue to be dominated by macroalgae (Chiappone et al. 2002). Chronic epizootics have long-term, more gradual effects that may be exacerbated by links between deteriorating environmental conditions and lowered or differential immunocompetence of susceptible species or increased pathogen virulence (Edinger et al. 1998, Dube et al. 2002, Harvell et al. 2002). Links between physical and/or chemical stressors and disease outbreaks is of growing concern (Porter \& Meier 1992, Peters 1997, Santavy \& Peters 1997, Richardson 1998, Harvell et al. 1999, Kim \& Harvell 2002), posing further challenges for coral reef management (Antonius 1977, Hatcher et al. 1989, Richmond 1993). Increasing reports of disease outbreaks, inadequate descriptions of 'new' diseases, and potential but unverified links with 
environmental stress underscore the need for quantitative investigation addressing the impacts of diseases to reefs and the implications for reef management.

To date, few coral diseases have been adequately characterized (Richardson 1998), and their impacts on reef communities are often not well understood. Ecological aspects of diseases potentially affecting community structure (such as host breadth, geographic range, prevalence, seasonality, infectiousness) are rarely experimentally addressed, as most efforts concentrate on the identification of causative agents and disease etiology and pathology (Rützler \& Santavy 1983, Smith et al. 1996, 1998, Geiser et al. 1998, Richardson et al. 1998, Ritchie \& Smith 1998). However, such information is vital for reef health assessment and should be incorporated in monitoring and management strategies. For example, white-band disease (WBD) was implicated as the primary cause of a shift in dominance to Agaricia species in Caribbean reefs after over $3000 \mathrm{yr}$ of dominance by Acropora (Gladfelter 1982, Bythell \& Sheppard 1993, Aronson \& Precht 1997, Aronson et al. 1998, Patterson et al. 2002). Nagelkerken et al. (1997) documented the geographic range of sea-fan Aspergillosis outbreaks in the

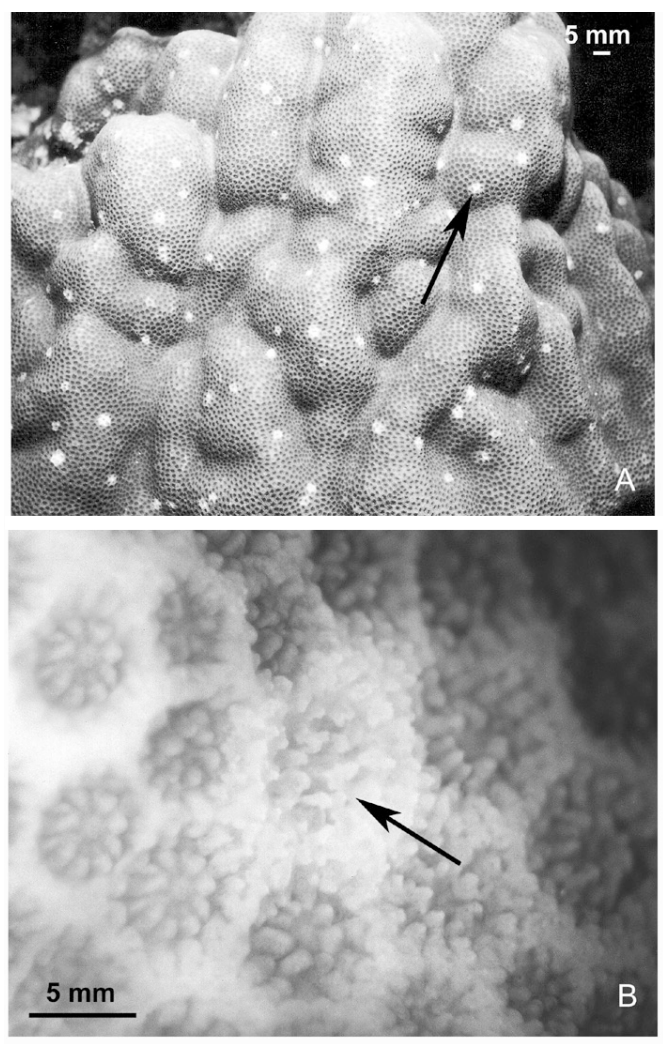

Fig. 1. Porites ulcerative white-spot disease (PUWS). Appearance of PUWS (arrows) (a) on massive Porites colony on Sumilon Island reef and (b) on P. attenuata (close-up)
Caribbean. Host and geographic range is predicted to increase, however, since the tissue concentrations of defensive compounds produced by many gorgonians did not inhibit the fungal pathogen (Kim et al. 2000). Further, water temperature (Alker et al. 2001) and fan age (Dube et al. 2002) affected gorgonian chemical defense, implicating warming sea temperatures in sea fan immunocompetence and the potential for directional selection on population structure. Awareness of the extent and nature of the role that epizootics play in reef communities would allow the incorporation of disease monitoring into management.

Coral diseases in the Indo-Pacific are not as well documented as those of the Caribbean (Goreau et al. 1998), and it is therefore difficult to draw conclusions concerning disease effects to reefs in this region. To date, only black-band and white-band diseases have been recorded from the region (Antonius 1985, Coles 1994, Littler \& Littler 1996, Miller 1996). Other 'conditions' have been reported, but without characterization and experimental documentation of infectiousness. In French Polynesia, Le Campion-Alsumard et al. (1995) described a potentially pathologic condition in Porites lobata caused by a fungal-algal association. The fungus Scolecobasidium sp. was associated with necrotic patches on several coral species in the Indian Ocean (Raghukumar \& Raghukumar 1991), and Loya et al. (1984) described tumors in Platygyra spp. on the Great Barrier Reef, although causal relationships were not proven in either case. The coralline lethal orange disease (CLOD) pathogen, infecting reef-building coralline algae, was first observed in the South Pacific by Littler \& Littler (1995). 'Yellow-band disease', described by Korrûbel (1998) from the Arabian Gulf, affects acroporids and poritids. These initial reports suggest that disease impacts to Indo-Pacific reefs may be underestimated.

This paper reports a previously undescribed coral disease affecting the genus Porites in the Central Philippines. In August 1996, during part of a transplantation project, small ( 3 to $5 \mathrm{~mm}$ diameter), discrete ovoid bleached lesions (Fig. 1) were observed on transplanted fragments of $P$. attenuata growing in Bais Bay, Negros Oriental (Raymundo 2002). A survey of the immediately surrounding reef revealed lesions on other Porites species as well. Infected colonies have been present on the reef since that time. Presented here is a description of the new disease. We address the following questions: (1) What are the signs of the disease? (2) How does the disease progress within a colony and what are the long-term effects on colony health? (3) Is there evidence of the presence of an infectious agent? (3) What is the host range of the disease and does severity differ between species? (4) What is the prevalence of the disease on reefs in the Central Philippines? 


\section{MATERIALS AND METHODS}

Progression and seasonality of disease. Sumilon Island, an uninhabited island (Fig. 2), was selected for long-term study, as disease prevalence was very high, Porites attenuata colonies were numerous, and reef structure allowed for easy monitoring of marked colonies. In February 1998, 25 affected colonies were tagged and 3 randomly selected branches were marked on each colony; 5 healthy colonies were tagged to serve as reference against which to monitor general colony health. An initial branch count estimated colony size. Bimonthly monitoring involved censusing all branches within a colony that showed lesions, and counting the number of lesions per branch on marked branches. The color of living tissue, the estimated proportion of dead skeleton per colony, and the presence and appearance of coalesced lesions were noted. The final census was completed in July 1999, after a 17 mo period.

Infection intensity was characterized as the number of branches infected per colony and the number of lesions per branch. Correlation between infection intensity and colony size was analyzed using linear regression analysis. Two exceptionally large colonies showed very low intensities of infection throughout the monitoring. Lesions in these colonies were identical to those in other colonies, but infection intensity represented greater than 3 standard deviations from the average colony response. Low infection intensity could be the result of several factors, such as elevated immune response or differential rates of progression, but as the objective of this test was to examine the average colony response, these colonies were treated as outliers and excluded from the analysis.

Regional prevalence of PUWS in central Philippines. The main objective at this initial stage was to determine the geographic extent of affected reefs in proximity to Bais Bay, where the disease was first observed. No attempt was made to select reefs with a particular level of health or environmental stress. A total of 10 reefs were surveyed in the central Visayas region (Fig. 2).

Each reef was surveyed using three $25 \mathrm{~m} \times$ $1 \mathrm{~m}$ belt-transects parallel to the shore. Transects were laid on the nearshore reef flat, the reef crest, and the forereef. Previous multiple transects at $3 \mathrm{~m}$ depth-intervals to $15 \mathrm{~m}$ in Bais Bay had revealed that prevalence was not depth-related $\left(\mathrm{r}^{2}=-0.071 ; \mathrm{p}>0.05\right.$; $F=0.07$ ). The following data were obtained for each transect: substrate cover (live hard coral, newly dead coral, rock, sand, rubble, soft coral), number of non-Porites colonies, identification and number of Porites spp. colonies, and number of infected colonies of each species. As massive species are difficult to identify in situ, massive Porites were treated as a single group. Extremely rare branching species, such as $P$. latistella, were not included in the statistical analysis and were never observed to be infected. Between-species prevalence was calculated per transect as the number of infected colonies of Species A/total number of colonies present of Species A. These data were analyzed using Friedman's test, as they did not meet the assumptions of normality. Prevalence of the disease per reef was calculated per transect as the number of infected Porites spp. colonies/total number of Porites spp. colonies.

Tests for transmission of lesions. Experiments were performed by grafting diseased branches onto healthy colonies and branches to test the hypothesis that lesions are transmissible. These were carried out in both laboratory aquaria, at Silliman University Marine Laboratory, and on the Sumilon Island reef. Laboratory experiments allow rigorous control, but conditions in aquaria are very different from those in the field: the captive

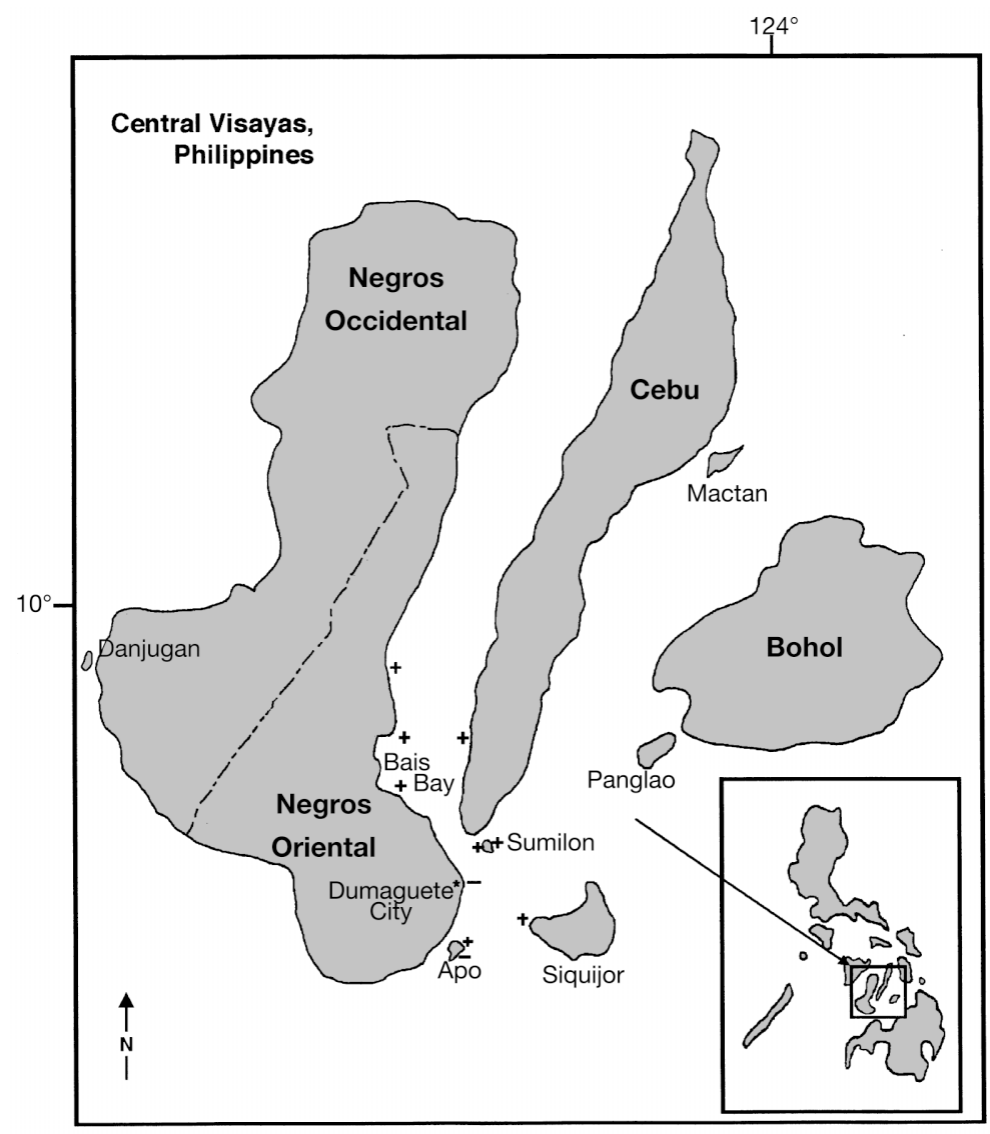

Fig. 2. Map of Central Visayas, Philippines, showing 10 reefs surveyed (+) reef with PUWS; (-) reef without PUWS 
Table 1. Porites ulcerative white-spot disease (PUWS). Experimental design of laboratory innoculation experiment

\begin{tabular}{|lcc|}
\hline Treatment & $\begin{array}{c}\text { Contact between fragments } \\
\text { (fragment aquarium }\end{array}$ \\
\hline $\begin{array}{l}\text { Disease aquaria } \\
\text { Containing diseased } \\
\text { fragments }(\mathrm{n}=5)\end{array}$ & $\begin{array}{c}\text { Direct physical } \\
(\mathrm{n}=1)\end{array}$ & $\begin{array}{c}\text { Waterborne } \\
(\mathrm{n}=1)\end{array}$ \\
$\begin{array}{l}\text { Control aquaria } \\
\text { Containing healthy }\end{array}$ & $\begin{array}{c}\text { Direct physical } \\
\text { fragments }(\mathrm{n}=3)\end{array}$ & $\begin{array}{c}\text { Waterborne } \\
(\mathrm{n}=1)\end{array}$ \\
\end{tabular}

setting creates physiologic stressors for experimental animals, so field trials were also undertaken to study transmission of the disease under natural conditions.

Preliminary laboratory experiments were conducted from October 2 to November 20, 1998. Eight 201 aquaria were supplied with independent water sources, aeration and shade. Each aquarium contained 2 clinically healthy, non-clonal branches obtained from the reef adjacent to the marine sanctuary, an uninfected site on Apo Island (Fig. 2), and fixed upright with marine epoxy in PVC cups. The experimental design is presented in Table 1. Diseased branches with active lesions (from Sumilon Island) were placed in 5 aquaria: one healthy branch was placed in direct physical contact with a single lesion on the diseased branch in each aquarium (mean surface area in contact with a lesion $=6.2 \pm 1.8 \mathrm{~mm}$ ), while the other healthy branch was positioned at the opposite end of the aquarium (distance between diseased and healthy branches $=32 \mathrm{~cm}$ ). This allowed an assessment of whether direct contact, rather than waterborne contact, was required for lesions to appear. Three healthy fragments were placed in the other 3 aquaria in the positions described above, to serve as controls for the effect of direct tissue contact between fragments. Placement of the aquaria was randomized on shaded outdoor laboratory tables. It was observed that lesions disappeared on the original diseased fragments after $2 \mathrm{wk}$ in aquaria, so these fragments were replaced with new ones to ensure continuous exposure to active lesions. When replacing diseased branches, care was taken to use the same contact point on the exposed fragment. Fragments were checked every $3 \mathrm{~d}$ for appearance, size and location of lesions and overall health over a period of 2 mo.

Field experiments were set up in late June 1999 on Sumilon reef, between 3 and $7 \mathrm{~m}$ depth. We selected 37 clinically healthy Porites attentuata colonies for in situ experimentation (22 disease treatments, 15 healthy reference treatments). These were grafted on June 30,1999. To reduce the possibility of clonal artifacts, colonies receiving grafts were not immediate neighbors. Diseased fragments, 4 to $5 \mathrm{~cm}$ long with 5 to 8 lesions, were broken off using a hammer and chisel from 10 nearby colonies. We grafted 3 diseased fragments, each from a different parent colony, onto haphazardly selected branches on each of 22 healthy colonies using cable ties; 3 healthy branches, obtained from separate lesion-free colonies, were grafted onto each of 3 branches on the remaining 15 healthy colonies to serve as reference. Colonies were censused 3 and 5 wk after innoculation, as previous observations had revealed that lesions take 2 to 3 wk to develop. Distance between new lesions and the nearest grafted branch was measured on each colony. If a lesion was found near an adjacent infected colony, this distance was also measured. The distance of lesions to the nearest graft in disease versus healthy treatments, and between the 2 census periods were tested using the Mann-Whitney $U$-test.

Data on the number of lesions per colony were normalized by log-transformation, and the number of lesions in diseased versus healthy grafts was analyzed using repeated-measures ANOVA; 2 colonies were removed from the calculations as they had developed very severe infections (150 lesions) by $5 \mathrm{wk}$. We considered these colonies outliers, as their severity of infection represented a very large departure from the average colony response ( $>3 \mathrm{SD}$ from the mean).

\section{RESULTS}

\section{Description and progression of disease}

The disease initially appears as round-to-ovoid, well-circumscribed, bleached foci of intact tissue, 3 to

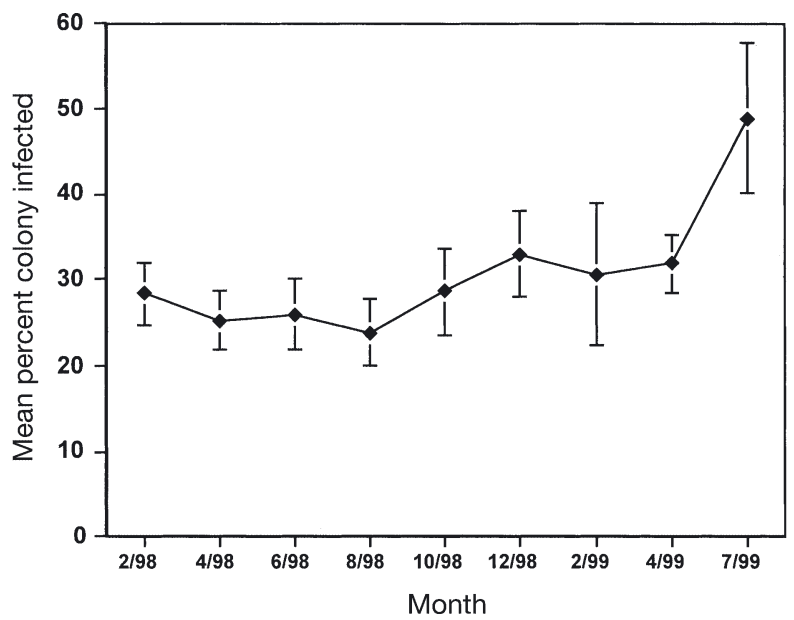

Fig. 3. Temporal variation in PUWS infection of Porites attenuata colonies in situ; mean $( \pm \mathrm{SE})$ percent infection per colony, $\mathrm{n}=25$ diseased colonies monitored for $17 \mathrm{mo}$ 
$5 \mathrm{~mm}$ in diameter, affecting 3 to 4 polyps and the surrounding coenosteum. On several occasions, bleached polyps with extended tentacles were observed within foci, suggesting that bleaching or loss of pigmentation may be the initial event in disease progression. Bleached foci either recovered (i.e. regained zooxanthellae), or progressed to complete tissue loss with exposure of the underlying skeleton (Fig. 1). As corallites of genus Porites are among the smallest of all scleractinian species, it was usually not possible to verify the presence of polyps when tentacles were retracted, without magnification. Therefore, the term 'lesion' as used in this paper refers to these ovoid, bleached foci that may or may not contain intact tissue. Lesions first appeared in a localized area of a colony, either singly or in small clusters. Within 2 mo, unpigmented foci were observed throughout a colony. Observations made without marking or damaging tissue revealed that discrete lesions commonly disappeared between bimonthly visits, and new ones continually appeared in other locations on the colony. Sites of previous lesions appeared to be covered with normal tissue, and it was not known whether dead polyps were overgrown with healthy tissue, or if the lesion had regressed. Severe infection with numerous lesions resulted in coalescence of adjacent lesions, forming irregular patches $(>3 \mathrm{~cm})$ of exposed skeleton that were colonized by green filamentous algae within 3 to $4 \mathrm{~d}$. Healthy coral tissue did not overgrow coalesced lesions, and such patches usually progressed to involve greater portions or the entire colony head, eventually resulting in death.

At the start of monitoring, the 25 tagged diseased colonies displayed visible lesions but were otherwise healthy; living tissue had the characteristic golden-brown color, with little or no dead skeleton. Colony size varied from 68.8 to $5056.2 \mathrm{~cm}^{2}$, the number of censused branches displaying lesions ranged from 9 to 79, and the average number of lesions per branch ranged from 2 to 25. Severity throughout the 17 mo sampling period ranged from mild to severe, with a slight increase in infection per colony from October to December 1998 (Fig. 3) during the rainy season. Infection had decreased by January 1999, but significantly increased again in many colonies by July (ANOVA: $F=2.29$, p < 0.05; Fig. 3). In October 1998, 2 to 3 lesions appeared on each of 2 of the 5 reference colonies, but had disappeared by December, and all other reference colonies remained lesion-free throughout monitoring.

Infection in some colonies was variable and increased over time; in others, it varied little and remained relatively low. Colony size was positively associated with the number of branches infected (percent infection per colony versus colony size: $\mathrm{r}^{2}=0.34$, $\mathrm{df}=21$, p < 0.05), but was not significantly associated with the number of lesions per branch (mean lesions per branch versus colony size: $\mathrm{r}^{2}=0.09$, $\mathrm{df}=21, \mathrm{p}>$ 0.05). Throughout monitoring, lesions were observed on all tagged diseased colonies during all sampling months. Although the average number and position of the lesions varied considerably per colony over the 17 mo monitoring period, at no time did they completely disappear from any colony (Fig. 4). Only 4 of
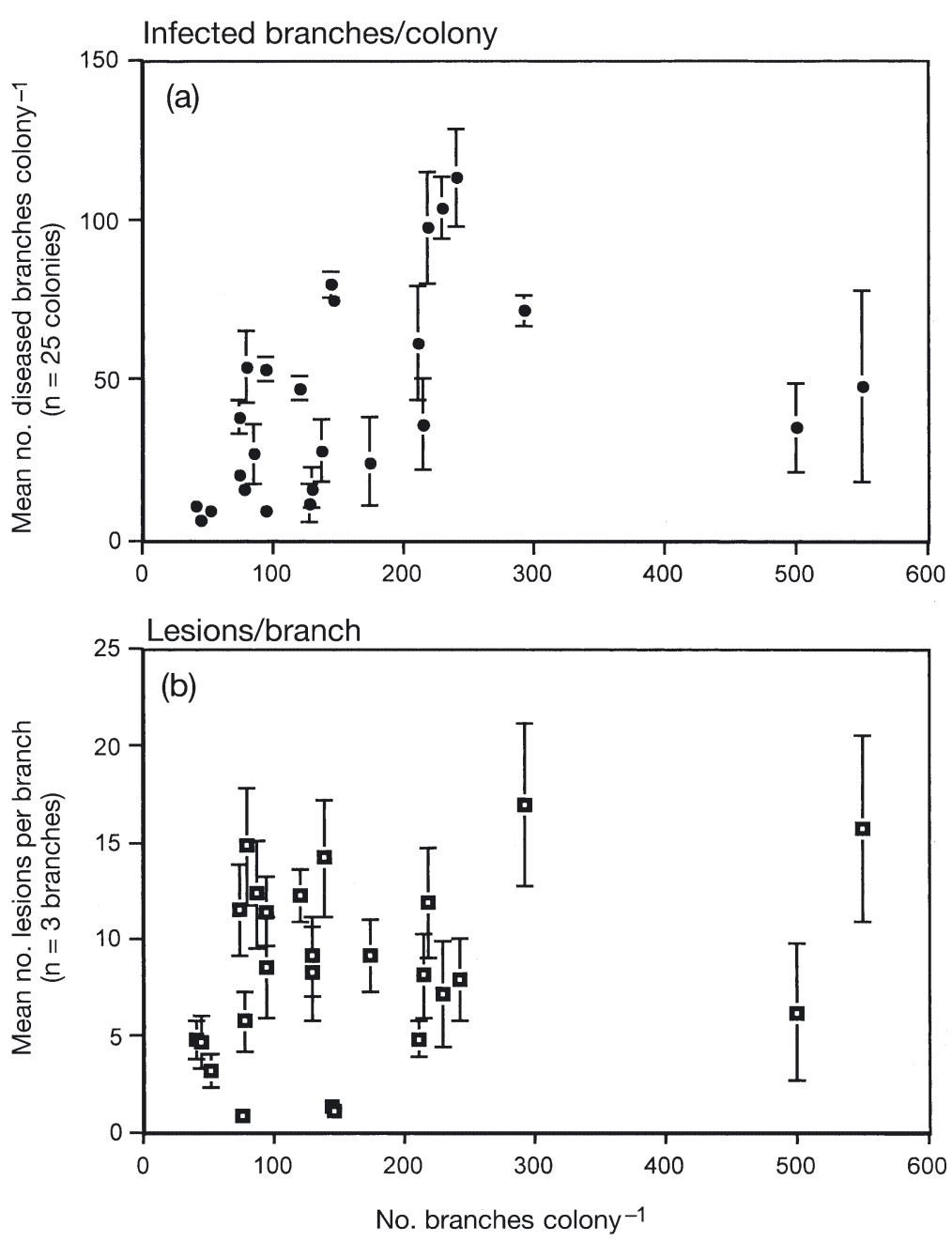

Fig. 4. (a) Mean $( \pm \mathrm{SD})$ number of infected branches per Porites attenuata colony and (b) mean $( \pm \mathrm{SE})$ number of lesions per branch as a function of colony size at Sumilon Island. Pooled data for entire monitoring period of $17 \mathrm{mo} ; \mathrm{n}=25$ colonies 


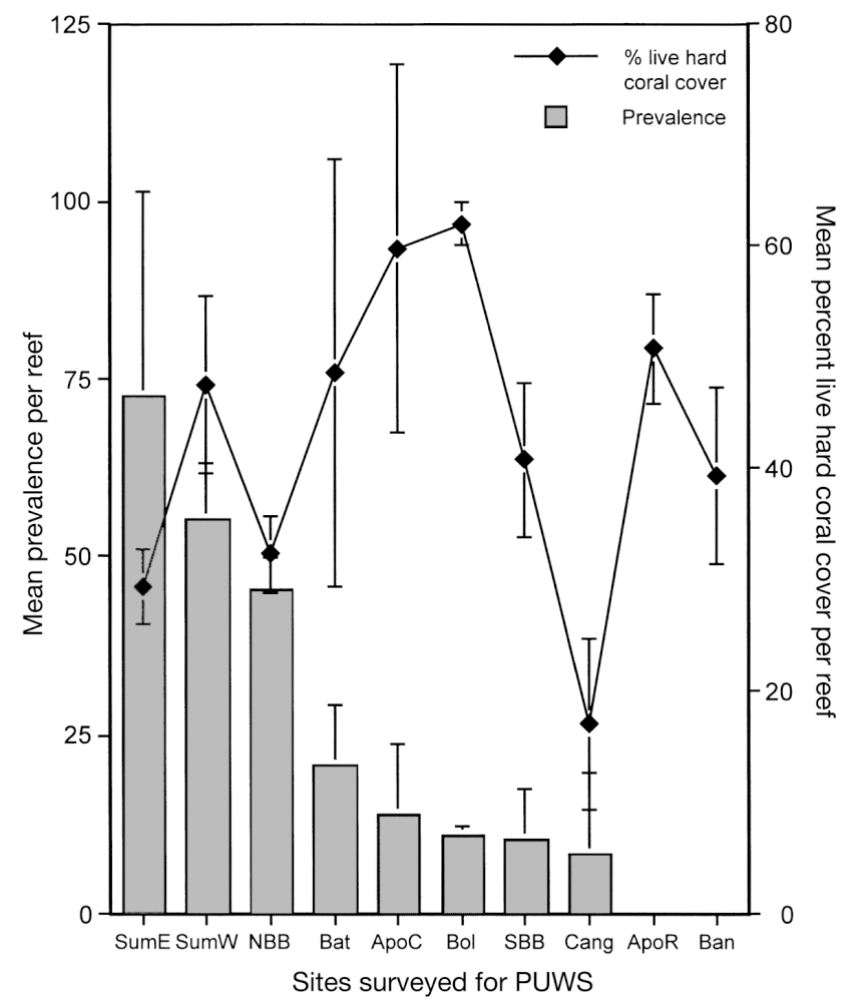

Fig. 5. Mean $( \pm \mathrm{SE})$ disease prevalence on Porites spp. reefs as a function of live hard-coral cover, where prevalence = no. infected colonies/total no. colonies; SumE, SumW: east and west sides of Sumilon Island respectively; NBB/SBB: north and south Bais Bay, Negros Oriental, respectively; Bat: Bato, Cebu; ApoC, ApoR: Cogon reef and Marine Reserve, Apo Island, respectively; Bol: Bolisong, Negros Oriental; Cang: Cangalwang, Siquijor Island; Ban: Bantayan, Negros Oriental. $\mathrm{n}=3$ transects per reef

the 25 diseased colonies surveyed retained their normal tissue color and did not lose extensive tissue throughout the study, despite a continual display of lesions. At the end of the 17 mo period, 2 colonies ( $8 \%$ ) had died and 14 (56\%) had lost a large portion (70 to $90 \%$ ) of coral tissue. During sampling 6 diseased colonies and 1 reference colony disappeared, presumably dislodged by anchor damage. All other reference colonies were lesion-free at the end of the study.

\section{Prevalence of infection on reefs and host range}

Of 10 surveyed reefs, 8 contained Porites attentuata colonies infected with PUWS (Fig. 5). The prevalence of the infection varied greatly between reefs. Reefs that were close to each other (i.e. Sumilon Island east and west; north and south Bais Bay; Apo Island Marine Reserve and Cogon reef) did not display similar levels of prevalence. The disease was absent from both Apo
Island reefs (Marine Reserve and Cogon) during 1997, but appeared 1 yr later on the Cogon reef, necessitating a resurvey. These resurvey data are presented in Fig. 5. No infected colonies have been observed on the Apo Island Marine Reserve to date, though a few infected colonies have appeared on the Bantayan reef. The mean percentage infection of Porites spp. ranged from 0 (Apo Island Marine Reserve and Bantayan reef) to $72.6 \pm 16.5 \%$ (Sumilon Island, east side). There was no significant correlation between total prevalence and live hard-coral cover $\left(\mathrm{r}^{2}=3.0 ; F=0.963\right.$; $\left.\mathrm{p}>0.05\right)$.

A total of 6 branching species exhibited signs of PUWS (Porites attenuata, P. cylindrica, P. nigrescens, $P$. horizontallata, $P$. rus and $P$. annae). Massive species could not be identified in situ, but the high frequency of occurrence of infection in massives suggests that the most common species ( $P$. australiensis, $P$. lobata, $P$. lutea and $P$. solida) were probably susceptible. Withinspecies prevalence was variable, but associated with density; the more common species were infected to a greater degree (Spearman rank-correlation: rho = 0.609). No significant difference in prevalence between species was found as a function of species density (Friedman's $c^{2}$ corrected for ties $=3.543$; df $=2$; $\mathrm{p}>0.05)$, suggesting a lack of differential susceptibility between species. PUWS was absent on large ( $>2 \mathrm{~m}$ diameter) massive colonies, though it was very common on smaller massives.

\section{Infection experiments}

In the preliminary laboratory innoculation experiment, 4 out of 5 healthy fragments in direct physical contact with a lesion developed lesions within 1 wk. The lesions did not appear as discrete, round spots, but rather resembled the condition of lesions that had coalesced, with irregular bleached areas spreading from the point of contact. Lesions increased in size until they circumscribed the fragment, leaving only the top few millimeters of tissue intact by the termination of the experiment. After 1 mo the lesions ranged from 19 to $43 \mathrm{~mm}$ in length, while the size of the contact area between fragments averaged $6.1 \mathrm{~mm}$. In addition, 3 out of the 5 fragments in 'diseased' aquaria with only waterborne contact (Table 1) developed lesions that began at the fragment base and spread upward; 2 of these died. None of the fragments in control treatments developed lesions and remained healthy throughout the experiment, although 1 fragment touching a healthy control developed a small $(10 \mathrm{~mm})$ bleached area around the contact point. Since lesions increased in size, becoming much larger than the diameter of contact between fragments, and healthy-to-healthy grafts exhibited no response, it is unlikely that lesions 
were caused by tissue damage due to direct physical contact between branches.

Field innoculation results are summarized in Fig. 6. Of the $22(95.5 \%)$ healthy colonies grafted with a diseased branch, 21 developed lesions within 5 wk. Of the 15 control colonies, $6(40 \%)$ also developed lesions. During the 3 wk census, we observed that several of the healthy branches grafted onto the healthy control colonies developed lesions; colonies with post-graft infected branches had also developed lesions by the fifth week. The source colonies for these healthy fragments remained disease-free throughout the $5 \mathrm{wk}$ experiment.

The difference in nearest distance from grafts to lesions between disease and control grafts was not significant (Mann-Whitney $Z=-1.9102 ; \mathrm{p}>0.05$ ), and graftto-lesion distances also did not differ in disease grafts between the 2 census periods (Mann-Whitney $Z=$ $0.372 ; \mathrm{p}>0.05$ ). This may be explained by the great variability in distances during both censuses: lesions developed very far from a graft but very near an infected neighbor, making it difficult to trace the source of infection. Lesions often occurred in clusters, although mean cluster size did not increase over time (ANOVA $F=1.319 ; \mathrm{p}>0.05)$. The total number of lesions on colonies with diseased versus control grafts was significantly different (ANOVA $F=7.7$; $p<0.05$; Fig. 6a, Table 2). Infection increased over time in the diseasegrafted colonies, and all colonies survived to $5 \mathrm{wk}$.
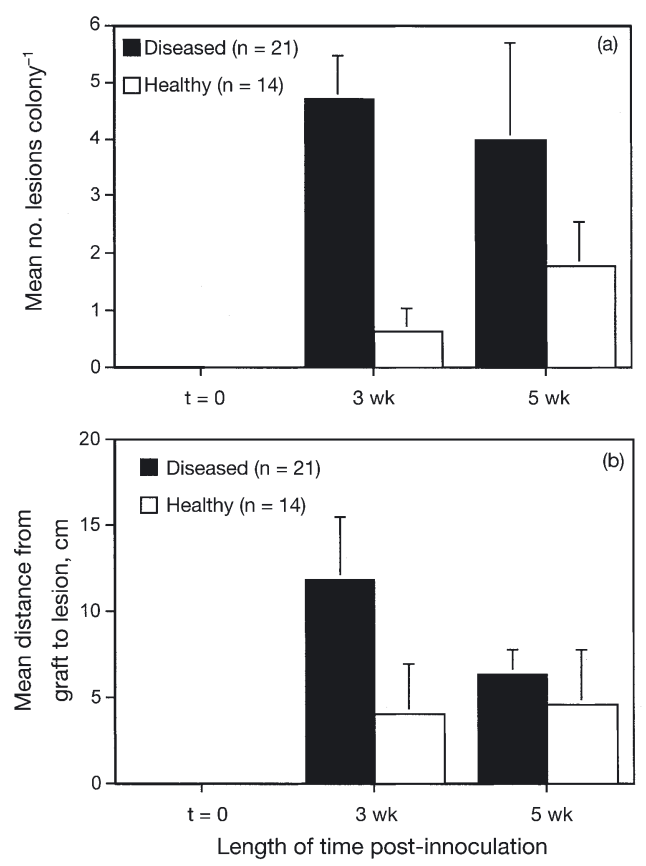

Fig. 6. Field innoculation of healthy Porites attenuata colonies with PUWS-infected branches and healthy control branches. (a) Mean $( \pm \mathrm{SE})$ number of lesions per colony at 2 census periods; (b) mean distance from graft to lesions
Table 2. Results of the repeated-measures ANOVA on total number of lesions on disease vs control-graft colonies of Porites attenuata. Censuses made at 3 and $5 \mathrm{wk}$

\begin{tabular}{|c|c|c|c|}
\hline Source & df & F-ratio & $\mathrm{p}$-value \\
\hline \multicolumn{3}{|l|}{ Treatment } & 0.0068 \\
\hline \multicolumn{4}{|l|}{ Repeat } \\
\hline 3-wk vs 5-wk census & 1 & 7.0313 & 0.0100 \\
\hline \multicolumn{4}{|l|}{ Interaction } \\
\hline Treatment $\times$ Repeat & 1 & 7.3015 & 0.0087 \\
\hline
\end{tabular}

\section{DISCUSSION}

This is the first report of a new coral syndrome affecting a dominant reef-building genus in the Indo-Pacific. PUWS appears to be a very prevalent disease, but a slow killer. Prevalence of PUWS among poritid species was very high $(22 \pm 7 \%$ for all poritid colonies; and $72 \%$ on 1 reef) and $80 \%$ of the surveyed reefs contained infected colonies. These values are similar to those for Aspergillosis (39\% of Gorgonia spp. in the Caribbean [Nagelkerken et al. 1997] and $47 \%$ of Gorgonia spp. in the Florida Keys [Kim \& Harvell 2002]), and Plague Type II (20.1\% of Dichocoenia stokesi colonies [Richardson et al. 1998]). In contrast, reported prevalence values for black-band disease (BBD) are generally lower: $0.2 \%$ in the Virgin Islands (Edmunds 1991), $0.72 \%$ in the Florida Keys (Kuta \& Richardson 1996), $8.6 \%$ for Siderastrea siderea and $2.2 \%$ for Montastrea annularis in the Caribbean (Bruckner et al. 1997), with the Great Barrier Reef showing the highest prevalence (19\%; Miller 1996).

The rate of tissue loss was lower for PUWS than that reported for other diseases; Richardson et al. (1998) reported tissue loss of up to $2 \mathrm{~cm} \mathrm{~d}^{-1}$ with Plague Type II infections, and Nagelkerken et al. (1997) noted tissue loss of $<52 \%$ in Aspergillosis infections. BBD can result in $<75 \%$ tissue loss in 6 mo (Edmunds 1991). PUWS clearly has a slower onset and progression (2 colonies died within $17 \mathrm{mo}$ ) and some colonies showed lesions for extended periods without significant tissue loss. Recovery, however, was rare and only noted in colonies that displayed $<5$ lesions for $<1$ mo. Major disease effects on heavily infected colonies occurred by 9 mo, when one-third to one-half colony tissue loss occurred, and mortality followed beyond this point. This aspect, combined with high prevalence in a dominant genus, suggests the potential for long-term impacts of this disease on reef communities. Observations in the course of other surveys have shown that the disease is not limited to the immediate study area. In addition to formal transect surveys, infected colonies 
have been observed on other reefs throughout the Central Philippines. Other reports from the Great Barrier Reef (A. Baird pers. comm.) and Indonesia (I. Bachtiar pers. comm.) suggest that the disease may occur outside the Philippines.

Innoculation studies suggest that PUWS is transmissible; $95.5 \%$ of colonies in situ and $70 \%$ of healthy fragments in laboratory aquaria developed lesions after direct exposure to diseased tissue. The source of infection was difficult to trace in the field grafting trial, as lesion position often suggested infection from a neighboring colony, and lesion distances over time did not suggest spreading from a particular source. The 3 wk interval between grafting and the first census may have provided sufficient time for the disease to rapidly spread throughout a colony, obscuring any pattern of spreading from a source. Porites attenuata has a branching morphology, and the 3 grafts were haphazardly scattered throughout each colony to ensure adequate exposure to the pathogen. However, tracing the appearance of lesions relative to specific grafts was difficult. Future attempts could be improved by using massive colonies and by grafting diseased tissue onto a single point on the colony.

In 6 field reference grafts (out of 15), healthy grafted branches displayed lesions at $3 \mathrm{wk}$, and the colony to which the branch was grafted was infected by $5 \mathrm{wk}$. Spread of the disease through reference colonies was slower than spread through experimental colonies, and the distance from graft to lesions was correspondingly smaller (Fig. 6b). A daily census would have allowed a more discriminating view of the pattern of development of lesions, but was not logistically possible. It is difficult to trace the means of infection of these reference colonies. It is possible that source colonies were temporarily asymptomatic when reference fragments were removed for grafting, but harbored the pathogen(s). However, as the source colonies remained disease-free, it is more likely that the slight tissue damage to fragments caused by removal and grafting could have provided a point of entry for a waterborne pathogen after grafting. In addition, the significant difference in lesion number between disease and reference grafts, and the increase in number over time, makes the possibility of a previously existing infection unlikely. Furthermore, healthy colonies on the same reef remained virtually disease-free for over 17 mo (even those adjacent to diseased colonies), while infected colonies showed lesions continually throughout that period with no abatement. Given that field experiments are by nature less controlled, that the disease prevalence on Sumilon reef was very high $(72 \%)$, and that the mechanism of transmission has not yet been ascertained, infection of reference colonies is not an unforeseen result.
It is possible that the signs of disease we observed were the result of a secondary infection or an unusually localized bleaching response. It was difficult to mark sites of lesions without damaging tissue, and the distance to the study site made it impossible to visit daily to follow the fate of lesions. Therefore, fulfillment of Koch's postulates is necessary to establish the identity of the pathogen and verify that it is the primary cause of the symptoms observed. Koch's postulates provide a procedure to demonstrate that a putative pathogen is the causal agent of a disease (Richardson 1998).

Examining potential links between temperature, bacterial infection and bleaching is currently a point of interest in disease research, given the prediction of increased frequency and severity of El Niño Southern Oscillation (ENSO) events (Hoegh-Guldberg 1999). Bleaching in the coral Oculina patagonica was induced by bacterial infection (Kushmaro et al. 1997, 1998, Toren et al. 1998), and high water temperature was implicated in a disease affecting the octocoral Briareum asbestinum. During the 1998 ENSO event in the Florida Keys, most individuals of this octocoral bleached; many subsequently became necrotic, and an infectious agent was implicated in the high mortality observed (Harvell et al. 2001). The recently described Vibrio coralliilyticus, a Red Sea pathogen of Pocillopora damicornis, elicited a similar pattern of lesions to those described here for PUWS; namely, the appearance of white spots that progressed to large regions of full tissue-thickness loss (Ben-Haim \& Rosenberg 2002, Ben-Haim et al. 2003). Lesion development and tissue loss was more rapid at temperatures above $26^{\circ} \mathrm{C}$, a finding that is consistent with the proposed pathogenesis of PUWS (T. Reynolds \& J. Raymundo unpubl.). In the Central Philippines, coral bleaching during the 1997-1998 ENSO occurred from August to December 1998, although poritids were not severely affected and none of the monitored colonies bleached. August 1998, in fact, showed the lowest severity of infection of the entire monitoring period. Little evidence of any link with the ENSO event is therefore discernible. However, high sea temperatures may allow certain bacterial pathogens to proliferate or induce virulence, leading to disease. High temperatures may also cause physiological stress, leading to decreased immune competence and/or bleaching, and may benefit certain pathogens as well. This has been documented in Aspergillosis; high temperatures stimulated growth of the fungal pathogen, while lowering the efficacy of defensive chemistry in its host (Alker et al. 2001). As PUWS was first observed and elucidated during the start of an ENSO event, and continued to increase in prevalence and severity over the course of this event and into the months that followed, it is likely that elevated sea tem- 
peratures played a role in the disease process. The lesions of PUWS begin as discrete round, bleached foci; this may represent an atypical bleaching response.

The amount of dead coral and rubble on a reef is associated with stressors such as storm damage, siltation, destructive fishing, or disease. Prevalence of PUWS on the surveyed reefs varied between reefs with differing ratios of dead to live hard coral, although not significantly. Low amounts of live coral relative to dead coral can indicate a stressed reef and possible increased susceptibility to disease, although our results do not suggest a correlation between prevalence and decreasing live coral cover in the 10 reefs surveyed. On the other hand, an infectious disease that spreads between live colonies may require a minimum colony density in order to spread. This was suggested by our observations on the Cangalwang reef, where prevalence increased per transect as coral density increased.

Relatively little is known about coral diseases in the Indo-Pacific area. Only BBD and WBD have a documented circumtropical distribution (Rützler \& Santavy 1983, Antonius 1985, Coles 1994), although betweenspecies differences in signs of disease may confound the interpretation of geographic range. While its extent on reefs in the region is still undetermined, the occurrence of this new epizootic PUWS, as well as other recent reports (Korrubel \& Riegl 1998, Antonius 1999) suggest that its prevalence in the Indo-Pacific may be underestimated. A greater effort to document IndoPacific disease outbreaks would allow a more balanced global perspective of coral disease prevalence and its impact on reef communities.

Acknowledgements. The authors wish to thank K. Kim, G. Smith, E. Peters and A. Maypa for comments and advice throughout this work. A. Maypa and A. Apao assisted with fieldwork. Thanks also for comments from 3 anonymous reviewers that greatly improved the manuscript. This project was funded by NSF Grant No. INT-9512721 to C.D.H. and L.J.H.R.

\section{LITERATURE CITED}

Alker AP, Smith GW, Kim K (2001) Characterization of Aspergillus sydowii (Thom et Church), a fungal pathogen of Caribbean sea fan corals. Hydrobiologia 460:105-111

Antonius A (1977) Coral mortality in reefs: a problem for science and management. Proc 3rd Int Coral Reef Symp 2: $617-624$

Antonius A (1985) Coral diseases in the Indo-Pacific: a first record. PSZN I: Mar Ecol 6:197-218

Antonius A (1999) Halofolliculina corallasia, a new coralkilling ciliate on Indo-Pacific reefs. Coral Reefs 18(3):300

Aronson RB, Precht WF (1997) Stasis, biological disturbance, and community structure of a Holocene coral reef. Paleobiol 23:326-346

Aronson RB, Precht WF, Macintyre IG (1998) Extrinsic control of species replacement on a Holocene reef in Belize: the role of coral disease. Coral Reefs 17:223-230

Ben-Haim Y, Rosenberg E (2002) A novel Vibrio sp. pathogen of the coral Pocillopora damicornis. Mar Biol 141:47-55

Ben-Haim Y, Thompson FL, Thompson CC, Cnockaert MC, Hoste B, Swings J, Rosenberg E (2003) Vibrio coralliilyticus sp. nov., a temperature-dependent pathogen of the coral Pocillopora damicornis. Int J Syst Evol Microbiol 53:309-315

Bruckner AW, Bruckner RJ, Williams EH Jr (1997) Spread of a black-band disease epizootic through the coral reef system in St. Ann's Bay, Jamaica. Bull Mar Sci 61:919-928

Bythell J, Sheppard C (1993) Mass mortality of Caribbean shallow corals. Mar Pollut Bull 26:296-297

Carpenter RC (1990) Mass mortality of Diadema antillarum. I. Long-term effects on sea urchin population dynamics and coral reef algal communities. Mar Biol 104:67-77

Chiappone M, Swanson DW, Miller SL, Smith SG (2002) Large-scale surveys on the Florida Reef Tract indicate poor recovery of the long-spined sea urching Diadema antillarum. Coral Reefs 21(2):155-178

Coles SL (1994) Extensive coral disease outbreak at Fahl Island, Gulf of Oman, Indian Ocean. Coral Reefs 13:242

Dube D, Kim K, Alker A, Harvell CD (2002) Size structure and geographic variation in chemical resistance of sea fan corals Gorgonia ventalina to a fungal pathogen. Mar Ecol Prog Ser 231:139-150

Edmunds PJ (1991) Extent and effect of black band disease on a Caribbean reef. Coral Reefs 10:161-165

Edinger E N, Jompa J, Limmon GV, Widjatmoko W, Risk M (1998) Reef degradation and coral biodiversity in Indonesia: effects of land-based pollution, destructive fishing practices and changes over time. Mar Pollut Bull 36(8):617-630

Geiser DM, Taylor JW, Ritchie KB, Smith GW (1998) Cause of sea fan death in the West Indies. Nature 394:137-138

Gladfelter WB (1982) White-band disease in Acropora palmata: implications for the structure and growth of shallow reefs. Bull Mar Sci 32:639-643

Goreau TJ, Cervino J, Goreau M, Hayes R and 14 others (1998) Rapid spread of diseases in Caribbean coral reefs. Rev Biol Trop 46(Suppl 5):157-171

Harvell CD, Kim K, Burkholder JM, Colwell RRl and 9 others (1999) Emerging marine diseases - climate links and anthropogenic factors. Science 285:1505-1510

Harvell CD, Kim K, Quirolo C, Weir J, Smith G (2001) Coral bleaching and disease: contributors to 1998 mass mortality in Briareum asbestinum (Octocorallia, Gorgonacea). Hydrobiologia 460:97-104

Harvell CD, Mitchell CE, Ward JR, Altizer S, Dobson AP, Ostfeld RS, Samuel MD (2002) Climate warming and disease risks for terrestrial and marine biota. Science 296: 2158-2162

Hatcher BG, Johannes RE, Robertson AI (1989) Review of research relevant to the conservation of shallow water tropical marine ecosystems. Oceanogr Mar Biol Annu Rev $27: 337-414$

Hoegh-Guldberg O (1999) Climate change, coral bleaching and the future of the world's coral reefs. Mar Freshw Res 50:839-866

Hughes TP (1994) Catastrophes, phase shifts, and large-scale degradation of a Caribbean coral reef. Science 265: 1547-1551

Kim K, Harvell CD (2002) Aspergillosis of sea fan corals: disease dynamics in the Florida Keys, USA. In: Porter J, Porter K (eds) The Everglades, Florida Bay, and Coral Reefs of the Florida Keys: an ecosystem handbook. CRC Press, Boca Raton, FL, p 813-824 
Kim K, Kim PD, Alker AP, Harvell CD (2000) Chemical resistance of gorgonian corals against fungal infections. Mar Biol 137:393-401

Kim K, Dobson AP, Gulland FMP, Harvell CD (in press) Diseases and the conservation of marine diversity. In: Norse E, Crowder L (eds) Marine conservation biology: the science of maintaining the sea's biodiversity. Island Press, Washington, DC

Korrûbel JL, Riegl B (1998) A new coral disease from the southern Arabian Gulf. Coral Reefs 17:22

Kushmaro A, Rosenberg E, Fine M, Loya Y (1997) Bleaching of the coral Oculina patagonica by Vibrio AK-1. Mar Ecol Prog Ser 147:159-165

Kushmaro A, Rosenberg E, Fine M, Ben Haim Y, Loya Y (1998) Effect of temperature on bleaching of the coral Oculina patagonica by Vibrio AK-1. Mar Ecol Prog Ser 171:131-137

Kuta KG, Richardson LL (1996) Abundance and distribution of black band disease on coral reefs in the northern Florida Keys. Coral Reefs 15:219-224

Le Campion-Alsumard T, Golubic S, Priess K (1995) Fungi in corals: symbiosis or disease? Interaction between polyps and fungi causes pearl-like skeleton biomineralization. Mar Ecol Prog Ser 117:137-147

Liddell WD, Ohlhorst SL (1986) Changes in benthic community composition following the mass mortality of Diadema at Jamaica. J Exp Mar Biol Ecol 95:271-278

Littler MM, Littler DS (1995) Impact of CLOD pathogen on Pacific coral reefs. Science 267:1356-1360

Littler MM, Littler DS (1996) Black band disease in the South Pacific. Coral Reefs 15:20

Loya Y, Bull G, Pichon M (1984) Tumor formations in scleractinian corals. Helgol Meeresunters 37:99-112

Miller I (1996) Black band disease on the Great Barrier Reef. Coral Reefs 15:58

Nagelkerken I, Buchan K, Smith GW, Bonair K and 8 others (1997) Widespread disease in Caribbean sea fans. I. Spreading and general characteristics. Proc 8th Int Coral Reef Symp I:679-682

Patterson KL, Porter JW, Ritchie KB, Polson SW, Mueller E, Peters EC, Santavy DL, Smith GW (2002) The etiology of white pox, a lethal disease of the Caribbean elkhorn coral, Acropora palmata. Proc Natl Acad Sci USA 99:8725-8730

Editorial responsibility: Albert Sparks,

Seattle, Washington, USA
Peters EC (1989) Symbiosis to pathology: are the roles of microorganisms as pathogens of coral reef organisms predictable from existing knowledge? Proc 6th Int Coral Reef Symp 1:205-210

Peters EC (1997) Chapter 6. Diseases of coral-reef organisms. In: Birkeland C (ed) Life and death of coral reefs. Chapman \& Hall, London, p 114-139

Porter JW, Meier OW (1992) Quantification of loss and change in Floridian reef coral populations. Am Zool 32(6):625-640

Raghukumar C, Raghukumar S (1991) Fungal invasion of massive corals. Mar Ecol 12:251-260

Raymundo LJ (2002) Mediation of growth by conspecific neighbors in transplanted fragments of the coral Porites attenuata Nemenzo in the Central Philippines. Coral Reefs $20(2): 263-272$

Richardson LL (1998) Coral diseases: What is really known? Trends Ecol Evol 13:438-443

Richardson LL, Goldberg WM, Carlton RG, Halas JC (1998) Coral diseases outbreak in the Florida Keys: Plague Type II. Rev Biol Trop 46(Suppl 5):187-198

Richmond RH (1993) Coral reefs: present problems and future concerns resulting from anthropogenic disturbance. Am Zool 33:524-536

Ritchie KB, Smith GW (1998) Description of Type II whiteband disease in acroporid corals. Rev Biol Trop 46 (Suppl 5):199-203

Rützler K, Santavy DL (1983) The black-band disease of Atlantic Reef corals. I. Description of the cyanophyte pathogen. PSZN I: Mar Ecol 4:301-319

Santavy DL, Peters EC (1997) Microbial pests: coral disease in the Western Atlantic. Proc 8th Int Coral Reef Symp 1: 607-612

Smith GW, Ives ID, Nagelkerken IA, Ritchie KB (1996) Caribbean sea-fan mortalities. Nature 383:487

Smith GW, Harvell CD, Kim K (1998) Response of sea fans to infection with Aspergillus sp. (fungi). Rev Biol Trop 46(Suppl 5):205-208

Toren A, Landau L, Kushmaro A, Loya Y, Rosenberg E (1998) Effect of temperature on adhesion of Vibrio strain AK-1 to Oculina patagonica and on coral bleaching. Appl Environ Microbiol 64:1379-1384

Submitted: February 12, 2003; Accepted: March 6, 2003 Proofs received from author(s): August 25, 2003 